\title{
MBTI TYPE PREDICTION USING IMAGES FROM INSTAGRAM
}

\author{
MUSSAYEVA D. ${ }^{1}$, KUANDYKOVA A. ${ }^{2}$, TALASBEK A. ${ }^{1}$, ORYNBEKOVA K. ${ }^{1}$, KARIBOZ D. ${ }^{1}$ \\ ${ }^{I}$ Suleyman Demirel University, 040900, Kaskelen, Kazakhstan \\ 2JSC “Kompra”, 010000, Nur-Sultan, Kazakhstan
}

Abstract. This article describes image based personality type prediction. With the help of the Instagram API, photos of respondents who previously passed the MBTI test were collected. As a result, 60 percent of accuracy was achieved. This work represents one of the solutions to determine what personality type a person belongs to without passing any tests, but simply uploading an image.

Keywords: Personality prediction, Image classification, CNN, Instagram API, MBTI.

\section{ИНСТАГРАМ ЖЕЛІСІНДЕГІ КЕСКІНДЕРДІ КОЛДАНУ АРҚЫЛЫ МВТІ ТИПІН БОЛЖАУ}

\author{
МУСАЕВА Д. ${ }^{1}$, КУАНДЫКОВА А. ${ }^{2}$, ТАЛАСБЕК А. ${ }^{1}$, ОРЫНБЕКОВА К. ${ }^{1}$, КАРИБОЗ Д. ${ }^{1}$ \\ ${ }^{\prime}$ Сулейман Демирел атындавы университет, 040900, Қаскелең, Қазақстан \\ 'ЖШС “Компра”, 010000, Нұр-Сұлтан, Қазақсттан
}

Аңдатпа. Берілген мақ̧ала ешбір тестілеусіз, адамның фотосуреті арқ̧ыль құандай МВТІ типіне жататындывын анықтайтын шешімдердің бірін ұсынады. Instagram API көмегімен бұрын МВТI тестінен өткен респонденттердің жеке фотосуреттері жиналып, сол арқыль зерттеу жүргізілді. Жұмыс нәтижесінде дәлдіктің 60 пайызына қ̧ол жеткізілді.

Түйінді сөздер: жеке тұлzаны болжау, кескіндерді классификащиалау, CNN, Instagram API, MBTI

\section{ПРОГНОЗ ТИПА МВТІ С ИСПОЛЬЗОВАНИЕМ ИЗОБРАЖЕНИЙ И3 INSTAGRAM}

\author{
МУСАЕВА Д. ${ }^{1}$, КУАНДЫКОВА А. ${ }^{2}$, ТАЛАСБЕК А. ${ }^{1}$, ОРЫНБЕКОВА К. ${ }^{1}$, КАРИБОЗ Д. ${ }^{1}$ \\ ${ }^{\prime}$ Уиверситет имени Сулеймана Демиреля, 040900, Каскелен, Казахстан \\ ${ }^{2}$ ТОО "Компра", 010000, Нур-Султан, Казахстан
}

\begin{abstract}
Аннотация. В данной статье описывается прогнозирование типа личности на основе изображений. C помощью Instagram API получили фотографии респондентов, ранее сдавщих тест MBTI. B результате была достигнута 60-прочентная точность. Эта работа представляет собой одно из решений, позволяющих определить, к какому типу личности принадлежит человек, не проходя никаких тестов, а просто загружая изображение.
\end{abstract}

Ключевые слова: предсказание личности, классификация изображений, CNN, Instagram API, MBTI

\section{Introduction}

The Myers-Briggs Type Indicator (MBTI) a questionnaire, which can determine psychological preferences of a person towards the world, other people and in decision making[1].

Scientists Krug and Johns did the MBTI ex- periment interrogating, approximately, 17000 people. They brought out six psycho points: Conscientiousness, Control, Tough Poise, Intelligence, Neuroticism and Extraversion. The results were independently confirmed by Boyle on the Cattell, Comrie and Eysenck scale [2]. 
E-I measurement defines extraversion and introversion. S-N measurement - Tough Poise (Sensitivity). T-F and J-P dimensions are Conscientiousness, Control, Intelligence, Openness, according to the Norman Big Five. MBTI focuses on cognitive characteristics, in contrast to other personality tools [3].

The MBTI is an opportunity to make the right decision while choosing a future profession, - say the Tiegers. Due to MBTI people can find the most appropriate job in which they can show maximum performance in building their career. They declare that personality type affects the quality of performing job responsibilities of chosen profession [4].

\section{Implementation}

One of the important stages in Machine Learning projects is the data collection part. Due to the lack of data, datasets from Kaggle and Google form that assembled in previous work were combined [5]. After scraping Images from Instagram accounts of responders more than 500 human faces were taken. To make the data collection process more accurate and faster, only the last 12 posts from each user were collected and only photos that are closer to the photo from the passport were chosen. The algorithm itself detects only the person's face and saves only this part as it is shown in Figure 1 below.
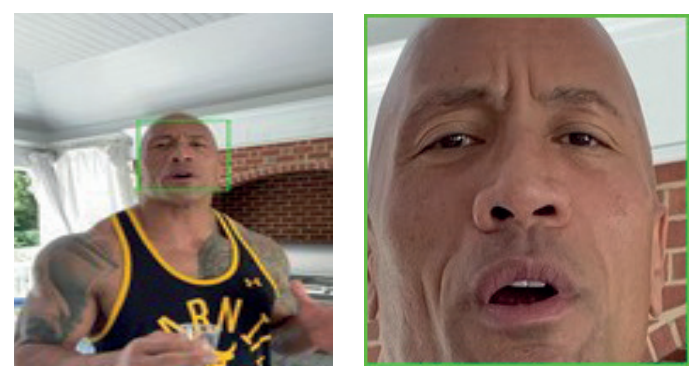

Figure 1. Image preprocessing [6]

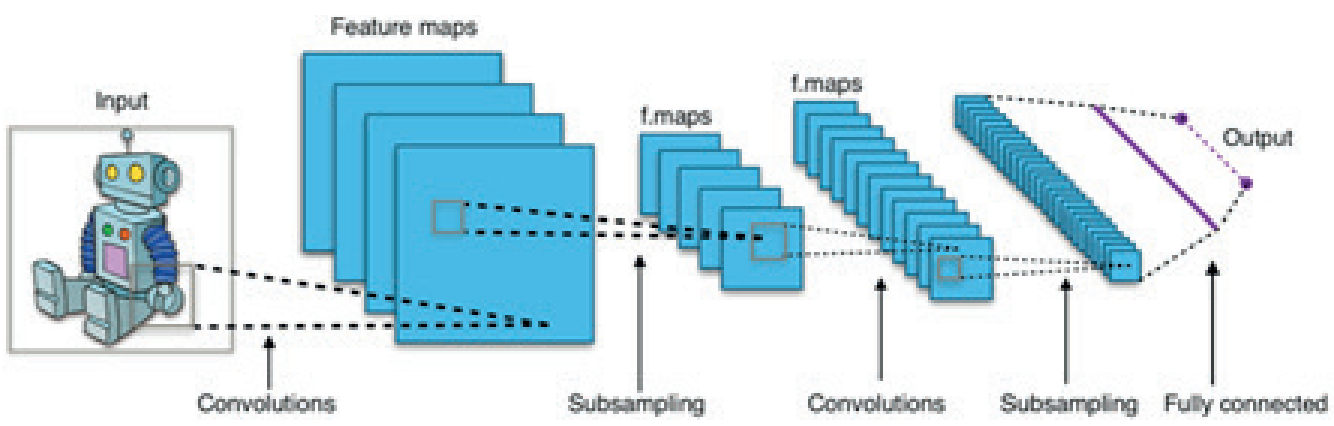

Figure 2. Convolutional Neural Network [8]
Table 1. Custom dataset with personality type

\begin{tabular}{|l|l|}
\hline Image & Type \\
\hline cristiano.jpg & INTP \\
\hline arianagrande.jpg & INFP \\
\hline therock.jpg & ENFP \\
\hline selenagomez.jpg & INFJ \\
\hline kyliejenner.jpg & INFP \\
\hline$\ldots$ & $\ldots$ \\
\hline joannagaines.jpg & INFP \\
\hline iza.jpg & INTP \\
\hline serenawilliams.jpg & INFJ \\
\hline ileana_official.jpg & INFP \\
\hline irfanhakim75.jpg & INTP \\
\hline
\end{tabular}

Each image in our dataset shown in Table 1 was converted to Grayscale to avoid complexities, the colored image is in 3 dimensional array whereas gray is one only. To normalize the pixel values of an image, it was divided by 255 , since this is the largest value that an array can take, to get a result from 0 to 1 . For each pixel an array of three digits describe the color scheme: RGB (Red, Green, Blue).

Convolutional Neural Network (CNN)

Convolutional Neural Network $(\mathrm{CNN})$ is the most used neural network model for the task of classifying images [7]. The CNN spends less time and space, due to the fact that it takes not every pixel individually, but a certain square, then rotates the pixel that is most suitable for the criteria. Alternatively, fully connected weight network from each pixel, $\mathrm{CNN}$ has sufficient weights to look at a tiny piece of the image as shown in Figure 2. 
The shape of Input Layer $64 \times 64$, three Convolutional layers with increasing filter size and left same values for kernel size as 5, with 1 stride length, padding 'same' and activation function 'ReLU' which is shown in Figure 3.

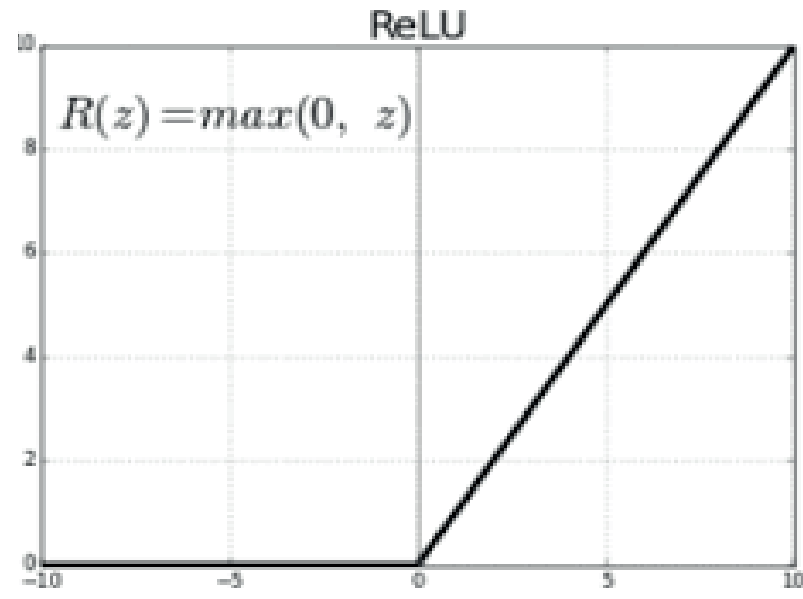

Figure 3. ReLU

Filter is a matrix for determining features from an image, it is a combination of connections. Filter size was increased because of features extraction from noisy data and each time combinations are getting complex, becomes abstract and hence we can work with larger size. Kernel size is the size of these convolutional filters, $5 \times 5$ square-shaped. Padding determines the size for output volumes based on input and to keep the same output volume size as the input is 'same padding', so it will add zeros around to the input volume. Immediately after the convolutional layer, the MaxPool2D pooling layer was used. In our case, it reduces the spatial dimension of output volume.
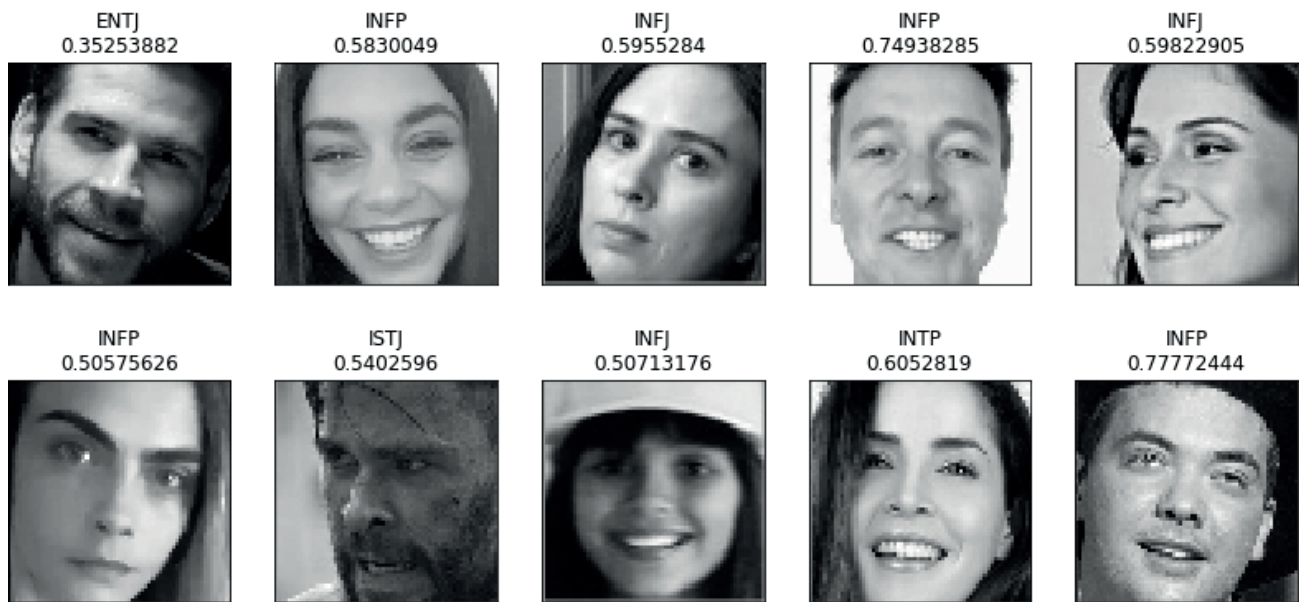

Figure 5. Results of datasets on jupyter
After convolutional layers we use one dropout layer to keep the network generalized and avoid overfitting data (caused by a complex model, performs well on training data but poor for unseen test data). To make classification we need fully connected layers without any complex structure, just a large piece of ready output data. To convert neurons of the convolutional layer it needs to be flattened, using the Dense layer to transfer 3-dimensional array to one dimensional. Softmax activation function that shown in Figure 4 is intended for categorical targets.

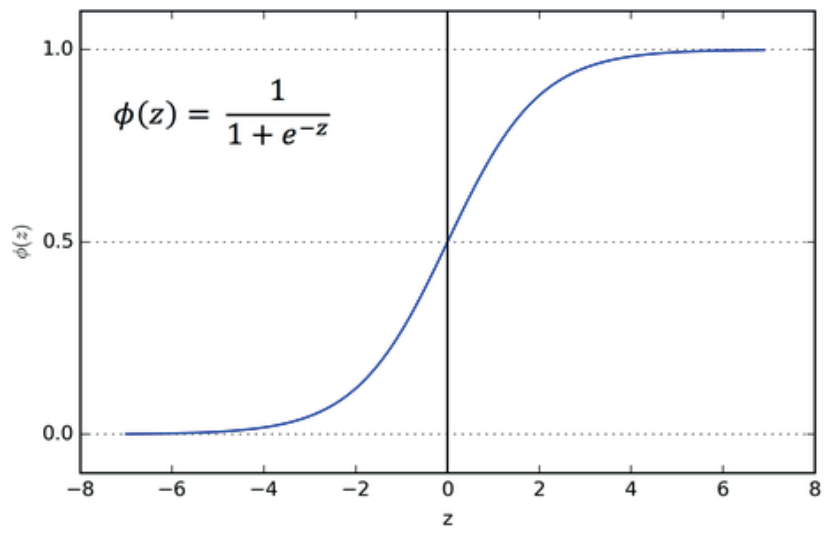

Figure 4. Softmax activation function

Optimizer determines how the learning proceeds and uses Adam optimizer with a learning rate of 0.001 .

\section{Results and conclusion}

After the model is completed training, accuracy of $55.07 \%$ and 2.61 loss value on average were achieved. Figure 5 illustrates custom images in JupyterLab with the predicted MBTI type and accuracy of them. 
This article describes whether facial As with all work related to machine learning, the features can tell which personality type a person limitation of this work is lack of data. Another belongs to. As a result, 60 percent probability was achieved. CNN gives high performance in images as it has filters and "condition detectors". thing that should be noticed is that CNN gives as some results but doesn't give us analysis of features and how they affect on prediction itself.

\section{REFERENCES}

1. Myers, Isabel Briggs with Peter B. Myers (1995) [1980]. Gifts Differing: Understanding Personality Type. Mountain View, CA: Davies-Black Publishing. ISBN 978-0-89106-074-1

2. GJ. Boyle, (1989). Re-examination of the major personality-type factors in the Cattell, Comrey, and Eysenck scales: Were the factor solutions by Noller et al. optimal? Personality and Individual Differences, 10, 1289-1299.

3. P.T. Costa, \& R.R. McCrae, (1992). NEO Personality Inventory. Psychological Assessment, 4, 5- 13.

4. Paul D. Tieger and Barbara Barron-Tieger. Do What You Are: Discover the Perfect Career for You Through the Secrets of Personality Type

5. Assem Talasbek, Azamat Serek. Personality Classification Experiment by Applying k-Means Clustering. International Journal of Emerging Technologies in Learning (iJET) 15(16):162.

6. Photo of actor. Available at: https://baigenews.kz/news/dueyn_dzhonson_zanyal trete_mesto_v_mire po_chislu_podpischikov_v_instagram/ Date of access [17.01.2020]

7. Nigam V. Understanding Neural Networks. From neuron to RNN, CNN, and Deep Learning (2018). Available at: https://towardsdatascience.com/understanding-neural-networks-fromneuron-to-rnn-cnn-and-deep-learning-cd88e90e0a90 Date of [17.02.2020]

8. CNN. Available at: https://towardsai.net/p/machine-learning/beginner-guides-to-convolutionalneural-network-from-scratch-kuzushiji-mnist-75f42c175b21 Date of access [17.01.2020]

\section{Information about authors:}

1. Mussayeva D. - B.S, Student of Master program, Suleyman Demirel University, Abylai Khan street $1 / 1$, Kaskelen

2. Kuandykova A. - B.S, Data Analyst, JSC "Kompra”, Mangilik Yel avenue, C4 /6, Nur-Sultan

3. Talasbek A. - MSc, Senior Lecturer, Suleyman Demirel University, Abylai Khan street 1/1, Kaskelen

Email: assem.talasbek@sdu.edu.kz

4. Orynbekova K. - MSc, Senior Lecturer, Suleyman Demirel University, Abylai Khan street 1/1, Kaskelen

5. Kariboz D. - MSc, Senior Lecturer, Suleyman Demirel University, Abylai Khan street 1/1, Kaskelen 